\title{
ANALISIS EFEKTIVITAS DAN EFISIENSI DISTRIBUSI RASKIN DI KELURAHAN TEMPULING KECAMATAN TEMPULING KABUPATEN INDRAGIRI HILIR
}

\author{
Rubiah \\ Program Studi Agribisnis Fakultas Pertanian UNISI \\ Email: rubiyah.rb788@gmail.com
}

\begin{abstract}
ABSTRAK
Program distribusi raskin merupakan program pemerintahyang memiliki tujuan untuk mengurangi beban pengeluaran rumah tangga miskin di Kelurahan Tempuling Kecamatan Tempuling Kabupaten Indragiri Hilir. Hal ini menjadi latar belakang sehingga perlu dilakukan kajian untuk melihat efektivitas dan efisiensi distribusi raskin agar penerima raskin memperoleh manfaat maksimal dari program distribusi raskin. Tujuan penelitian ini adalah: (1) Untuk mengetahui perbedaan harga antara harga patokan pemerintah dan harga ditingkat rumah tangga penerima raskin di Kelurahan Tempuling, (2) Untuk mengetahui tingkat efektivitas program raskin di Kelurahan Tempuling, (3) Untuk mengetahui tingkat efisiensi distribusi raskin di Kelurahan Tempuling. Pengambilan sampel dilakukan dengan rumus Slovin.Metode analisis data yang digunakan adalah analisis deskriptif kuantitatif. Hasil penelitian menunjukkan bahwa: (1) Perbedaan harga antara harga patokan pemerintah dan harga di tingkat rumah tangga penerima raskin sebesar Rp. 600,-. (2) Program distribusi raskin tidak efektif dengan ratarata tingakat efektivitas $31 \%$. (3) Program distribusi raskin efisien dengan nilai efisiensi 0,15 .
\end{abstract}

Kata Kunci : distribusi raskin, efektivitas, efisiensi

\section{PENDAHULUAN}

Kemiskinan merupakan suatu kondisi kehidupan serba kekurangan yang dialami seseorang sehingga tidak mampu memenuhi minimal kehidupannya. Standar minimal kebutuhan hidup ini berbeda antara satu daerah dengan daerah lain. Kebutuhan minimal tersebut meliputi kebutuhan untuk makanan terutama energi kalori sehingga kemungkinan seseorang bisa bekerja untuk memperoleh pendapatan. Patokan tingkat kecukupan kalori yang dijadikan acuan adalah sebesar 2100 kalori setiap orang per hari untuk makanan (Badan Pusat Statistik, 2006).

Berdasarkan pendataan sosial ekonomi tahun 2005, BPS membagi rumah tangga menurut kategori sangat miskin, miskin, dan mendekati miskin. Sangat miskin apabila kemampuan untuk memenuhi konsumsi makanan yang hanya mencapai 1900 per orang per hari 
plus kebutuhan dasar makanan. Miskin apabila kemampuan untuk memenuhi konsumsi hanya mencapai antara 1900s/d 2100 per orang per hari plus kebutuhan dasar non makanan. Mendekati miskin apabila kemampuanuntuk memenuhi kebutuhan konsumsi makanan yang hanya mencapai antara $2100 \mathrm{~s} / \mathrm{d}$ 2300 kalori per orang per hari plus kebutuhan dasar non makanan (BPS, 2006).

BPS juga menggunakan 14 variabel dalam pendataan sosial ekonomi penduduk untuk menentukan apakah satu rumah tangga layak atau tidak layak dikategorikan miskin. Empat Belas variabel tersebut adalah luas bangunan, jenis lantai, jenis dinding, fasilitas buang air besar, sumber air minum, sumber penerangan, jenis bahan bakar untuk memasak, frekuensi membeli daging, ayam dan susu selama seminggu, frekuensi makan sehari-hari, jumlah stel pakaian baru yang dibeli dalam setahun, akses ke puskesmas/poliklinik, lapangan pekerjaan, pendidikan tertinggi kepala rumah tangga, serta kepemilikan beberapa aset.

Pada saat munculnya program OPK (Operasi Pasar Khusus), Indonesia memang belum memiliki model bantuan pangan yang mantap seperti di Negara-negara maju. Oleh sebab itu, pola OPK dianggap menjadi alternatif yang paling rasional. Setiap tahunnya OPK dievaluasi dan terus melakukan penyempurnaan. Pada tahun 2002, nama program diubah dengan RASKIN (Beras untuk Keluarga Miskin) dengan tujuan agar lebih tepat sasaran (BULOG, 2006).

Kegiatan distribusi Raskin telah dimulai sejak tahun 1998 dimana program tersebut dapat memenuhi sebagian kebutuhan pangan (beras) sehingga diharapkan dapat mengurangi beban keluarga miskin. Dalam pelaksanaannya distribusi raskin mengalami beberapa kendala sehingga merugikan penerimanya. Pertama, salah sasaran, raskin yang semestinya dibagikan kepada keluarga miskin, ternyata jatuh ketangan kelompok masyarakat lain. Kedua, mutu beras jelek, meski pemerintah menjamin kualitas beras raskin terkondisi baik, namun banyak dikeluhkan, beras dibagikan apek, pera, kotor dan banyak kutu. Ketiga, dijual lagi ke pasar, raskin tidak dibagikan kepada yang berhak menerima, tetapi oleh petugas dijual ke penadah. Keempat, jumlah berkurang, yang seharusnya diterima adalah $15 \mathrm{Kg} / \mathrm{KK}$ tetapi kenyataannya kurang. Kelima, ada biaya tambahan, harga raskin yang semestinya dijual Rp 1.600/kg, terpaksa harus di bayar lebih, karena ada biaya tambahan seperti untuk biaya administrasi, ongkos angkut dan lainnya. Keenam, kesalahan data akibat tidak adanya koordinasi antara pemerintah baik dari pusat, provinsi, kabupaten sampai desa, jumlah orang miskin yang di data lebih besar dari yang sebenarnya, sehingga raskin yang dibagikan kurang. Ketujuh, menunggak setoran pembayaran , akibat tunggakan penjualan raskin di suatu daerah yang tidak disetorkan ke BULOG, maka bulog tidak mau menyalurkan lagi jatah raskin sebelum tunggakan dilunasi. Hal itu, amat merugikan Penerima Manfaat Raskin, karena mereka membeli secara kontan, sedangkan urusan penyetoran uang hasil pembelian tidak diketahui.

Berdasarkan data Badan Pusat Statistik (BPS, 2016) Propinsi Riau 
memiliki jumlah penduduk miskin yang cukup besar yaitu 562, 92 ribu atau 8,82 persen dari jumlah penduduk Riau. Angka tersebut menunjukkan tingkat kemiskinan yang cukup tinggi. Salah satu daerah yang tingkat kemiskinannya cukup tinggi di Provinsi Riau adalah Kabupaten Indragiri Hilir. Pada tahun 2016 tercatat $40 \%$ atau sebesar 163.092 jiwa dari 612.665 jiwa tergolong penduduk dengan tingkat kesejahteraan rendah. Jumlah rumah tangga miskin ini untuk setiap tahunnya terus meningkat. Sehingga dibutuhkan Pagu Raskin yang cukup tinggi untuk memenuhi kebutuhan keluarga yang ada di Kabupaten Indragiri Hilir.

Salah satu daerah yang ada di Kabupaten Indragiri Hilir yang mengalami peningkatan kemiskinan adalah Kecamatan Tempuling. Salah satu Desa/Kelurahan yang mengalami kemiskinan yang ada di Kecamatan Tempuling adalah Kelurahan Tempuling dengan jumlah penduduknya sebesar 4.519 jiwa dan jumlah rumah tangganya $1.080 \mathrm{KK}$ dengan jumlah rumah tangga miskin yaitu 205 KK. Dari kebijakan pemerintah bahwa setiap rumah tangga miskin mendapatkan subsidi berupa RASKIN yang per rumah tangga miskinnya mendapat $10-15 \mathrm{~kg}$ dengan harga antara Rp. 1.000,00$2.000,00 / \mathrm{kg}$ tergantung dari kebijakan Desa/Lurah masingmasing karena berkaitan dengan distribusi raskin tersebut. Desa /Kelurahan yang menerima raskin yang paling besar adalah Kelurahan Tempuling dengan total Pagu Raskin yang diterima yaitu, $3.075 \mathrm{Kg}$ dan masing-masing rumah tangga miskin menerima $15 \mathrm{~kg}$.

Berdasarkan uraian tersebut perlu adanya suatu penelitian yang mengkaji tentang efektifitas dan efisiensi distribusi program raskin yang akan diketahui hasil akhirnya berupa tingkat efektifitas program yang diukur melalui indikator keberhasilannya dan efisiensi yang berkaitan dengan program raskin tersebut sehingga dapat diketahui bagaimana hasil dari distribusi program raskin. Dari permasalahan tersebut, maka tujuan penelitian ini adalah sebagai berikut untuk mengetahui perbedaan harga antara harga patokan dengan harga aktual pada tingkat rumah tangga penerima beras miskin, untuk mengetahui tingkat efektifitas program distirbusi beras miskin dan untuk mengetahui tingkat efisiensi distirbusi dari penyaluran beras miskin hingga ke rumah tangga miskin di Kelurahan Tempuling Kecamatan Tempuling Kabupaten Indragiri Hilir.

\section{TINJAUAN PUSTAKA}

\subsection{Kemiskinan}

Kemiskinan dapat dibedakan menjadi tiga pengertian: kemiskinan absolut, kemiskinan relatif dan kemiskinan kultural. Seseorang termasuk golongan miskin absolut apabila hasil pendapatannya berada di bawah garis kemiskinan, tidak cukup untuk memenuhi kebutuhan hidup minimum: pangan, sandang, kesehatan, papan, dan pendidikan. Seseorang yang tergolong miskin relatif sebenarnya telah hidup di atas garis kemiskinan namun masih berada dibawah kemampuan masyarakat sekitarnya. Selanjutnya miskin kultural berkaitan erat dengan sikap seseorang atau sekelompok masyarakat yang tidak mau berusaha memperbaiki tingkat kehidupannya sekalipun ada usaha dari pihak lain yang membantunya. Kemiskinan 
telah berdampak pada jatuhnya kualitas hidup manusia secara total ditandai dengan sempitnya nalar, egoisme atau mau menang sendiri. Setiap masalah kemasyarakatan cenderung diselesaikan dengan adu otot, kekerasan, dan mengerahkan massa(Asy'arie, 2001).

\begin{tabular}{lcr}
\multicolumn{2}{c}{ Kemiskinan juga dapat } \\
diartikan & sebagai akibat & dari \\
ketiadaan & demokrasi, & yang
\end{tabular}
mencerminkan hubungan kekuasaan yang menghilangkan kemampuan warga suatu negara untuk memutuskan masalah yang menjadi perhatian mereka sendiri. Sehingga mayoritas penduduk kurang memperoleh alat-alat produksi (lahan dan teknologi) dan sumberdaya (pendidikan, kredit, dan akses pasar). Selain itu kurangnya mekanisme yang memadai untuk akumulasi dan distribusi (Basri, 2002).

Menurut Adelman, di daerah perkotaan, mayoritas kaum miskin adalah pekerja-pekerja tidak terlatih di sektor jasa-jasa. Para pekerja di sektor manufaktur (industri pengolahan), apakah mereka itu terlatih atau tidak, merupakan bagian 20-40 persen penduduk yang paling kaya. Jadi tenaga kerja tidak terlatih merupakan milik utama kaum miskin dan yang menentukan arah kemiskinan adalah adanya permintaan akan produktivitas daripada tenaga kerja mereka itu (Goudzwaard,1995).

Dalam kajian penelitian dengan objek kemiskinan, akan ditentukan indikan dari ciri atau sifat kemiskinan. BPS memberikan 14 kriteria yang dijadikan sebagai indikator keluarga miskin sebagai berikut:

1. Luas lantai bangunan tempat tinggal kurang dari $8 \mathrm{~m}^{2}$ per orang
2. Jenis lantai bangunan tempat tinggal terbuat dari tanah/bambu/kayumurahan

3. Jenis dinding tempat tinggal terbuat dari bambu/rumbia/kayu berkualitasrendah/tembok tanpa diplester

4. Tidak memiliki fasilitas buang air besar atau bersama-sama dengan rumah tangga lain

5. Sumber penerangan rumah tangga tidak menggunakan listrik

6. Sumber air minum berasal dari sumur/mata air tidak terlindung/sungai/air hujan

7. Bahan bakar untuk memasak sehari-hari adalah kayubakar/arang/minyak tanah 8. Hanya mengkonsumsi daging/susu/ayam satu kali dalam seminggu

9. Hanya membeli satu stel pakaian dalam setahun

10. Hanya sanggup makan sebanyak satu/dua kali dalam sehari

11. Tidak sanggup membayar biaya pengobatan di puskesmas atau poliklinik

12. Sumber penghasilan kepala rumahtangga adalah: petani dengan luaslahan 0,5 ha, buruh tani, nelayan, buruh bangunan, buruh perkebunan,atau pekerja lainnya dengan pendapatan dibawah Rp.600.000 per bulan

13. Pendidikan tertinggi kepala rumah tangga: tidak sekolah/tidak tamat SD/hanya SD

14. Tidak memiliki tabungan/barang yang mudah dijual dengan nilai Rp 500.000, seperti: sepeda motor (kredit/non-kredit), emas, ternak, kapal motor, atau barang modal lainnya.

\subsection{Program Raskin}


Program Raskin (Program Penyaluran Beras Untuk Keluarga Miskin) adalah sebuah program dari pemerintah sebagai upaya untuk mengurangi beban pengeluaran dari rumah tangga miskin. Program ini merupakan bentuk dukungan dalam meningkatkan ketahanan pangan untuk memberikan perlindungan sosial beras murah dengan jumlah maksimal 15 kg/Rumah Tangga Miskin/bulandan masing-masing seharga Rp 1600,00 per kg (netto) di titik distribusi. Program ini mencakup di seluruh provinsi, sementara tanggung jawab dari distribusi beras dari gudang sampai ke titik distribusi di kelurahan dipegang oleh Perum Bulog (Badan Urusan Logistik). Menurut Kementrian Koordinator Bidang Kesejahteraan Rakyat, Program Raskin adalah salah satu program penanggulangan kemiskinan dan perlindungan sosial yang diselenggarakan oleh Pemerintah Pusat berupa bantuan beras bersubsidi kepada rumah tangga berpendapatan rendah (rumah tangga miskin dan rentan miskin) (BULOG, 2012).

untuk Program Raskin $\begin{array}{r}\text { bertujuan } \\ \text { beban }\end{array}$ pengeluaran rumah tangga sasaran dalam memenuhi kebutuhan pangan pokok dalam bentuk beras.Program raskin bertujuan untuk membantu kelompok miskin dan rentan miskin mendapat cukup pangan dan nutrisi karbohidrat tanpa kendala. Efektivitas Raskin sebagai perlindungan sosial dan penanggulangan kemiskinan sangat bergantung pada kecukupan nilai transfer pendapatan dan ketepatan sasaran kepada kelompok miskin dan rentan.
Program raskin adalah program pemerintah untuk memberikan bantuan beras dengan harga penjualan bersubsidi kepada masyarakat miskin. Melalui program ini pemerintah menyediakan beras kepada masyarakat miskin sebanyak $15 \mathrm{~kg} / \mathrm{KK} /$ bulan. Beras diberikan tidak dengan cuma-cuma. Penerima bantuan raskin harus membayar dengan harga $\mathrm{Rp} 1.600$ per $\mathrm{kg}$ netto di titik distribusi. Sehingga selisih antara harga pasar yang seharusnya dibayar dengan harga yang sesungguhnya dibayar $(\mathrm{Rp} 1.600 / \mathrm{kg})$ oleh keluarga miskin menjadi besaran subsidi yang ditanggung oleh pemerintah per kilogramnya (Departemen Dalam Negeri dan Perum Bulog, 2006).

\subsection{Distribusi Raskin}

Distribusi merupakan penambahan kegunaan waktu, tempat dan pemilikan barang yang mencakup juga pengangkutan barang-barang dari tempat asal atau produksi lanjutan ke tempat penjualan. Dalam hal ini, distribusi mencakup berbagai bidang manajemen khususnya seperti, penjualan, pengiklanan, keuangan, pengangkutan dan pergudangan (Taff, 1994).

Peranan saluran distribusi dalam pemasaran tercermin dari biaya distribusi yang besarnya dapat melebihi biaya produksi, biaya promosi, biaya administrasi pemasaran dan biaya pemasaran lain. Peranan yang besar dapat ditunjukkan dengan kinerja yang baik terhadap fungsi-fungsi pemasaran yang dilakukan di setiap saluran (Purwadi, 2000).

Mekanisme pelaksanaan distribusi raskin, yaitu : 
1. Bupati/Wali kota mengajukan surat permintaan alokasi (spa) kepada Kadivre berdasarkan alokasi pagu raskin dan rumah tangga miskin penerima manfaat raskin di masing-masing Kecamatan atau Kelurahan.

2. spa yang tidak dapat dilayani sebagian atau seluruhnya dalam jangka waktu 3 (tiga) bulan, maka pagu dapat direlokasikan ke daerah lain dengan menerbitkan spa baru dengan menunjuk spa yang tidak dapat dilayani.

3. Berdasarkan spa, Kadivre menerbitkan SPPB (Surat Perintah Pengirimn Beras) untuk masing-masing

Kecamatan/Kelurahan/Desa

kepada satker (Satuan Kerja) raskin. Apabila terdapat tunggakan harga penjualan beras (HPB) pada periode sebelumnya maka penerbitan SPPB periode berikutnya ditangguhkan sampai ada pelunasan.

4. Berdasarkan sppb, satker raskin, mengambil beras di tempat penyimpanan Perum Bulog, mengangkut dan menyerahkan beras raskin kepada pelaksana distribusi di titik distribusi. Kualitas beras yang diserahkan, harus sesuai standar kualitas bulog. Apabila tidak memenuhi standar kualitas maka beras dikembalikan kepada satker raskin untuk ditukar/diganti.

5. Serah terima beras raskin dari satker raskin kepada pelaksanaan distribusi di titik istribusi dibuktikan dengan berita acara serah terima (bast) yang merupakan pengalihan tanggung jawab.
6. Pelaksana
distribusi
menyerahkan

rumah tangga miskin penerima manfaat raskin.

\subsection{Pengukuran Efektifitas}

Efektifitas adalah pengukuran keberhasilan dalam pencapaian tujuan yang telah ditentukan sebelumnya. Untuk peningkatan efektifitas ditingkat RTS (rumah tangga sasaran) pemerintah menerapkan sistem manajemen yang baik, manajemen waktu dan pengelolaan. Dalam perhitungan persentase efektifitas, dikategorikan efektif apabila mencapai minimal satu persen dan maksimal seratus persen (Sugiarto, 2010).

Pendistribusian raskin yang dilakukan oleh BULOG kepada RTM apabila hasilnya menunjukkan persentase yang semakin besar dapat dikatakan bahwa pendistribusian raskin semakin efektif. Demikian sebaliknya, semakin kecil hasilnya persentase maka menunjukkan pendistribusian raskin semakin tidak efektif.

Keefektifan distribusi Raskin dapat dinilai melalui indikator keberhasilan program raskin, yaitu ;

1. Tepat Sasaran Penerima Manfaat Raskin hanya diberikan kepada rumah tangga miskin penerima manfaat yang terdaftar dalam daftar penerima manfaat (DPM).

2. Tepat Jumlah

Jumlah beras Raskin yang merupakan hak penerima manfaat adalah sebanyak 10-15 $\mathrm{Kg} / \mathrm{RTM} /$ bulan selama 1 tahun.

3. Tepat Harga

Harga beras Raskin adalah sebesar Rp. 1.000/Kg-Rp. $1.600 / \mathrm{Kg}$ netto di titik distribusi.

4. Tepat Waktu

Waktu pelaksanaan distribusi beras kepada RTM penerima manfaat sesuai dengan rencana distribusi. 
5. Tepat Kualitas

Kualitas raskin yang didistribusikan kepada RTM harus memiliki kualitas yang baik sesuai dengan standar Bulog.

6. Tepat Administrasi

Terpenuhinya administrasi secara benar dan tepat waktu (Bulog, 2006).

\subsection{Efisiensi}

Efisiensi dapat didefinisikan sebagai peningkatan ratio outputinput yang dapat dicapai dengan cara yaitu pertama, output tetap konstan sedangkan input mengecil, kedua output meningkat sedangkan input tetap konstan, ketiga, output meningkat dalam kadar yang lebih tinggi daripada peningkatan input, keempat, output menurun dalam kadar yang lebih rendah daripada penurunan input (Rahim dan Dwihastuti, 2007).

Efisiensi pemasaran dapat terjadi yaitu, pertama, jika biaya distibusi dapat ditekan sehingga keuntungan yang diperoleh dapat lebih tinggi. Kedua, persentase perbedaan harga yang dibayarkan konsumen dan produsen tidak terlalu tinggi. Ketiga, tersedianya fasilitas fisik yang mendukung proses pendistribusian (Rahim dan Dwihastuti, 2007).

Setiap lembaga pemasaran yang terlibat akan mengambil keuntungan untuk mengambil jasa yang mereka berikan. Kegiatan fungsi pemasaran oleh lembagalembaga pemasaran akan mengakibatkan timbulnya biaya pemasaran. Besarnya biaya pemasaran akan berpengaruh terhadap harga beli konsumen. Hal ini disebabkan biaya pemasaran yang timbul akan menjadi tambahan harga pada barang yang harus ditanggung oleh konsumen. Semakin besar biaya pemasaran, maka akan mengurangi efisiensi pemasaran. Oleh karena itu untuk meningkatkan efisiensi pemasaran adalah dengan memperkecil biaya pemasaran. Untuk mengetahui efisiensi pemasaran pada setiap lembaga pemasaran yang terlibat, maka data yang diperoleh dianalisis dengan menggunakan rumus efisiensi pemasaran (Ep) (Downey dan Erickson, 1992) sebagai berikut :

$$
E p=\frac{\text { Biaya pemasaran }}{\text { Nilai Produk Dipasaran }}
$$

Jika :

Ep $>1$ berarti tidak efisien

Ep $<1$ berartiefisien

Ep $=0$ bearti belum efisien atau mencapai titik impas (BEP)

Harga beras raskin yang telah ditetapkan pemerintah yaitu sebesar Rp 1.000/ kg. Namun harga tersebut dapat berbeda jika telah berada ditangan penerima manfaat beras raskin. Harga dapat berkisar antara $\mathrm{Rp}$ 1.000-1.400 karena untuk biaya angkut atau biaya transportasidari titik distribusi ke penerima manfaat, serta dtetapkan beberapa kriteria diantaranya membebankan biaya ongkos kirim raskin kepada warga miskin, uang jasa malam selama beras berada di dalam gudang, uang pikul serta uang SPSI (Serikat Pekerja Seluruh Indonesia) (Sulaksono, 2003).

\section{METODE PENELITIAN \\ 3.1.Tempat dan Waktu Penelitian}

Penelitian ini dilaksanakan pada bulan Mei sampai Juli 2017 di Kelurahan Tempuling Kecamatan Tempuling Kabupaten Indragiri Hilir. Pemilihan lokasi ini dilakukan 
secara sengaja dengan pertimbangan bahwa lokasi tersebut merupakan distribusi raskin terbesar di Kecamatan Tempuling.

\subsection{Jenis dan Sumber Data}

Penelitian ini menggunakan data primer dan data sekunder. Data primer diperoleh dari wawancara dengan responden penerima Raskin dengan menggunakan kuisioner yang meliputi identitas respoden ( Umur, Pekerjaan, Pendidikan, Pendapatan, Jumlah Raskin yang diterima ). Data sekunder didapat dari instansi pemerintah seperti kantor camat dan kantor lurah Kecamatan Tempuling dan data informasi lainnya yang berkaitan dengan penelitian.

\subsection{Populasi dan Sampel}

Jumlah populasi penerima raskin di Kelurahan Tempuling yaitu 205 KK (Profil Kecamatan Tempuling 2015). Salah satu rumus yang dapat digunakan untuk menetukan jumlah sampel minimal jika diketahui ukuran populasi adalah Slovin (Umar 2003), dengan rumus sebagai berikut :

Keterangan :

$$
n=\frac{N}{1+N e^{2}}
$$

$$
\begin{aligned}
& \mathrm{N}=\text { Jumlah Populasi } \\
& \mathrm{n}=\text { Jumlah sampel } \\
& \mathrm{e}=\text { Kesalahan pengambilan } \\
& \text { sampel } 10 \% \\
& n=\frac{205}{1+205.0,10^{2}} \\
& =69 \text { responden }
\end{aligned}
$$

\subsection{Metode Analisis Data}

\subsubsection{Analisis perbedaan Harga}

Harga ditingkat retail (rumah tangga) adalah diwakili oleh harga di lembaga distribusi ditambah dengan biaya distribusi dan keuntungan lembaga penyalur raskin. Secara matematis dapat dinotasikan dengan rumus sebagai berikut.

$$
\operatorname{Prt}=\mathrm{Pi}+\mathrm{t}+\pi
$$

Dimana :

$$
\begin{aligned}
\text { Prt }= & \text { harga di tingkat retail } \\
& (\text { rumah tangga })(\mathrm{Rp} / \mathrm{kg}) \\
\mathrm{Pi}= & \text { harga di tingkat lembaga } \\
& \text { distribusi }(\mathrm{Rp} / \mathrm{kg}) \\
\mathrm{t}= & \text { biaya distribusi }(\mathrm{Rp} / \mathrm{kg}) \\
\pi= & \text { keuntungan oleh penyalur } \\
& (\mathrm{Rp} / \mathrm{kg})
\end{aligned}
$$

Selanjutnya, untuk melihat perbedaan harga patokan dengan harga tingkat retail (rumah tangga ) dipergunakan dengan menghitung selisisih kedua harga tersebut, yaitu :

Dimana :

$$
\Delta P=P r t-P p
$$

$$
\begin{aligned}
\mathrm{P}= & \text { perbedaan harga }(\mathrm{Rp} / \mathrm{kg}) \\
\mathrm{Pp}= & \text { harga patokan oleh } \\
& \text { pemerintah }(\mathrm{Rp} / \mathrm{kg})
\end{aligned}
$$

\subsubsection{Efektifitas}

Efektifitas dianalisis deskriptif yaitu dengan melihat pendistribusian beras miskin di Kelurahan Tempuling sesuai dengan indikator keefektifan distribusi raskin. Dikatakan efektif jika keenam indikator tersebut lebih besar atau sama dengan $80 \%$ dan jika dibawah $80 \%$ pendistribusian dikatakan tidak efektif.

\subsubsection{Efisiensi}

Efisiensi dianalisis dengan menghitung biaya distribusi di tingkat lembaga distribusi, dan nilai jual beras raskin yang dipasarkan. Untuk melihat tingkat efesiensi distribusi dihitung dengan menggunakan rumus Efisiensi Pemasaran (Ep) sebagai berikut :

Kriteria :

$$
E P=\frac{\text { Biaya Pemasaran }}{\text { Nilai Jual Produk Dipasaran }}
$$

Ep > 1 berarti pendistribusian tidak efisien 
Ep $<1$ berarti pendistribusian efisien

$\mathrm{Ep}=0$ bearti belum efisien atau mencapai titik impas (BEP)

( Downey dan Erickson, 1992 )

\section{HASIL DAN PEMBAHASAN}

\subsection{Analisis Perbedaan Harga}

Raskin merupakan subsidi pangan sebagai upaya pemerintah untuk meningkatkan ketahanan pangan dan memberikan perlindungan pada keluarga miskin melalui pendistribusian beras. Masing-masing keluarga akan menerima beras sebanyak $15 \mathrm{Kg} / \mathrm{KK}$ dengan harga netto Rp. 2.200 per Kg di titik distribusi.Pemerintah menetapkan harga Raskin sebesar Rp $1.600 / \mathrm{Kg}$ dengan maksud dapat meringankan beban pengeluaran untuk pangan bagi warga yang kurang mampu atau rumah tangga miskin. Namun harga tersebut berbeda setelah sampai ke tangan penerima manfaat raskin. Hal itu karena terdapat biaya tambahan seperti untuk biaya angkut, upah timbang dan transportasi.

Harga ditingkat rumah tangga penerima manfaat raskin diwakili oleh harga ditingkat Bulog ditambah dengan biaya-biaya selama proses pendistribusian. Hal ini dapat dilihat pada Tabel 1. Dari tabel 1, dapat dilihat bahwa untuk kelurahan Tempuling yaitu pagu raskin yang disalurkan adalah $3075 \mathrm{Kg}$ dengan jumlah rumah tangga miskin (RTM) yang menerima raskin sebanyak 205 KK. Harga raskin yang telah ditetapkan oleh BULOG yaitu sebesar 1600/Kg. Biaya-biaya yang terjadi selama proses pendistribusian yaitu biaya angkut dari Bulog, biaya transportasi hingga ke penerima manfaat, biaya penyusutan beras dan biaya upah timbang sebesar $\mathrm{Rp}$ 1.021.000 atau $\mathrm{Rp} 332$ untuk tiap kilogramnya. Total biaya tersebut merupakan jumlah dari biaya distribusi yang terjadi ditingkat kecamatan yaitu sebesar Rp 550.000 dan biaya distribusi di tingkat Kelurahan yaitu sebesar Rp 471.000. Dalam penyaluran beras miskin masing-masing pelaksana distribusi ditingkat kecamatan memperoleh keuntungan sebesar Rp 65.000 dan ditingkat kelurahan memperoleh keuntungan sebesar $\mathrm{Rp}$ 759.000. Sehingga total keuntungan yang diperoleh sebesar $\mathrm{Rp} 824.000$ atau Rp 268/Kg.

Untuk harga raskin pada rumah tangga miskin di Kelurahan Tempuling dapat dilihat pada tabel 2 . Berdasarkan tabel 2 diketahui bahwa harga ditingkat rumah tangga penerima raskin diperoleh sebesar Rp 2200/Kg. Harga tersebut menimbulkan perbedaan dengan harga patokan yang ditetapkan oleh pemerintah yaitu Rp 1600/Kg. Perbedaan harga tersebut yaitu sebesar Rp 600. Terjadinya perbedaan harga ditingkat rumah tangga karena dibebankan biayabiaya dan keuntungan yang diperoleh dari pelaksana distribusi. Jika dilihat dari hasil perhitungan dapat disimpulkan bahwa keuntungan yang diperoleh oleh pelaksana distribusi lebih besar dari biaya-biaya yang dikeluarkan selama proses pendistribusian. Seharusnya dalam pendistribusian beras bersubsidi ini keuntungan yang diambil dapat diminimkan, sehingga tidak memberatkan rumah tangga penerima raskin. 
Tabel 1. Total Biaya dan Keuntungan dari Pendistribusian Raskin di Kelurahan Tempuling Kecamatan Tempuling Kabupaten Indragiri Hilir

\begin{tabular}{|l|l|c|c|}
\hline No & \multicolumn{1}{|c|}{ Uraian } & Satuan & Jumlah \\
\hline 1 & Pagu Raskin & $\mathrm{Kg}$ & 3.075 \\
\hline 2 & Harga beli Pihak Kecamatandi Bulog & $\mathrm{Rp} / \mathrm{kg}$ & 1.600 \\
\hline 3 & Harga Jual Pihak Kecamatan & $\mathrm{Rp} / \mathrm{kg}$ & 1.800 \\
\hline 4 & Biaya di Pihak Kecamatan & & \\
\hline & a. Transportasi Kecamatan- Kelurahan & $\mathrm{Rp}$ & 150.000 \\
\hline & b. Upah bongkar di Kecamatan & $\mathrm{Rp}$ & 200.000 \\
\hline \multicolumn{2}{|l|}{ c. Upah angkut di Kecamatan -Kelurahan } & $\mathrm{Rp}$ & 200.000 \\
\hline Biayadi Pihak Kecamatan & $\mathrm{Rp}$ & 550.000 \\
\hline Penerimaan & $\mathrm{Rp}$ & 615.000 \\
\hline Keuntungan & $\mathrm{Rp}$ & 65.000 \\
\hline 5 & Harga beli di Kecamatan & $\mathrm{Rp}$ & 1.800 \\
\hline 6 & Harga jual Tingkat Kelurahan & $\mathrm{Rp}$ & 2.200 \\
\hline 7 & Biaya Pihak di Kelurahan & $\mathrm{Rp}$ & 150.000 \\
\hline \multicolumn{2}{|l|}{ a. Upah bongkar di Kelurahan } & $\mathrm{Rp}$ & 100.000 \\
\hline & b. Upah Timbang & $\mathrm{Rp}$ & 221.000 \\
\hline \multicolumn{2}{|l|}{ c. Biaya Susut Beras } & $\mathrm{Rp}$ & 471.00 \\
\hline Biaya di Pihak Kelurahan & $\mathrm{Rp}$ & 1.230 .000 \\
\hline Penerimaan & $\mathrm{Rp}$ & 759.000 \\
\hline Keuntungan & $\mathrm{Rp}$ & 1.021 .000 \\
\hline 10 & Total Biaya & $\mathrm{Rp}$ & 824.000 \\
\hline 11 & Total Penerimaan & & \\
\hline 12 & Total Keuntungan & & \\
\hline
\end{tabular}

Sumber : Data Primer Diolah, 2017

Tabel 2. Harga Raskin pada Rumah Tangga Miskin di Kelurahan Tempuling Kecamatan Tempuling Kabupaten Indragiri Hilir

\begin{tabular}{|l|l|c|c|}
\hline No & \multicolumn{1}{|c|}{ Uraian } & Satuan & Jumlah \\
\hline 1 & Harga di Kantor Lurah & $\mathrm{Rp} / \mathrm{kg}$ & 2.200 \\
\hline 2 & Harga Patokan Pemerintah & $\mathrm{Rp}$ & 1.600 \\
\hline 3 & Perbedaan Harga & $\mathrm{Rp}$ & 600 \\
\hline
\end{tabular}

Sumber : Data Primer diolah 2017

Harga raskin di tingka trumah tangga miskin akan menjadi tidak wajar jika melebihi dari harga yangtelah ditetapkan karena keuntungan dari pendistribusian yang besar. Biayabiaya yang terjadi dalam pendistribusian dapat diminimalkan melalui efisiensi distribusi raskin ke titik akhir distribusi. Dengan begitu harga yang diterima oleh masyarakat miskin tidak berbeda jauh dengan harga yang ditetapkan Bulog. Hal ini senada dengan hasil penelitian Sari (2007) di Desa Securai Utara Kecamatan Balaban Kabupaten Langkatyang berpendapat bahwa tingkat perbedaan harga antara harga patokan pemerintah dengan harga aktual yang diterima oleh penerima manfaat sebesar Rp.400. Hal tersebut dikarenakan adanya biaya-biaya dan 
keuntungan yang diperoleh oleh pelaksana distribusi.

\subsection{Tingkat \\ Distribusi Raskin}

\section{Keefektifan}

Keefektifan pendistribusian beras miskin di nilai berdasarkan indikator-indikator tertentu dalam mencapai tujuan program pendistribusian raskin yang telah ditetapkan. Indikator-indikator keefektifan distribusia raskin ini yaitu ketetapan sasaran, jumlah, harga, waktu, kualitas dan administrasi.Adapun hasil analisis tingkat efektifitas pendistribusian raskin berdasarkan 6 indikator dapat dilihat pada tabel 3. Dari tabel 3, dapat dilihat bahwa pendistribusian raskin di Kelurahan Tempuling tidak efektif. Hal ini dapat dilihat dari ketepatan indikator, tingkat efektifitas ketepatan rata-rata hanya $31 \%$, sementara standar keefektifan adalah $\geq 80 \%$.

Tabel 3. Tingkat Keefektifan Distribusian Raskin di Kelurahan Tempuling Kecamatan Tempuling Kabupaten Indragiri Hilir.

\begin{tabular}{|l|l|c|c|c|c|}
\hline \multirow{2}{*}{ No } & \multirow{2}{*}{$\begin{array}{c}\text { Indikator Tingkat } \\
\text { Keefektifan }\end{array}$} & \multicolumn{2}{|c|}{ Tepat } & \multicolumn{2}{c|}{ Tidak Tepat } \\
\cline { 3 - 6 } & Jumlah & $\mathbf{( \% )}$ & Jumlah & $\mathbf{( \% )}$ \\
\hline 1 & Sasaran & 48 & 70 & 21 & 30 \\
\hline 2 & Jumlah & 0 & 0 & 69 & 100 \\
\hline 3 & Harga & 0 & 0 & 69 & 100 \\
\hline 4 & Waktu & 0 & 0 & 69 & 100 \\
\hline 5 & Kualitas & 32 & 46 & 37 & 54 \\
\hline 6 & Administrasi & 49 & 71 & 20 & 29 \\
\hline \multicolumn{2}{|l|}{ Rata-rata } & 21 & 31 & 48 & 69 \\
\hline
\end{tabular}

Sumber : Data Primer diolah 2017

\subsubsection{Tepat Sasaran}

Tingkat

keefektifan

pendistribusian raskin dikatakan efektif jika keenam indikator yang menunjukkan tingkat efektifitas berada diatas atau sama dengan 80\%.Tabel 11 menunjukkan bahwa $70 \%$ sampel mengatakan program pendistribusian raskin tepat sasaran. Dari data tersebut dapat disimpulkan bahwa program pendistribusian cukup efektif. Dikatakan cukup efektif karena sebagian besar penerima raskin sudah tepat sasaran. Namun, masih ada beberapa penerima manfaat raskin yang belum tepat sasaran, sebab belum sesuai dengan kriteria penerima manfaat raskin. Sasaran program raskin adalah rumah tangga miskin yang namanya telah terdaftar dalam Daftar
Penerima Manfaat (DPM) sebagai penerima manfaat beras raskin yang telah dikeluarkan oleh Badan Pusat Statistik (BPS). Namun yang terjadi di lapangan bahwa raskin tidak hanya dibagikan kepada keluarga miskin tetapi juga dibagikan kepada kelompok masyarakat lain, akibatnya warga miskin yang berhak menerima raskin hanya kebagian 7,5 kg hingga $10 \mathrm{~kg}$ dari jatah semestinya yaitu $15 \mathrm{Kg} / \mathrm{KK}$.

Sulitnya pembagian raskin dalam praktek lapangan, karena selalu terjadi perbedaan angka kemiskinan yang dikeluarkan dari BPS ataau BKKBN. Perbedaan angka inilah yang menyulitkan dalam pembagian raskin. Namun, dalaam hal ini data yang dipakai adalah data yang dikeluarkan oleh BPS karena 
data tersebut sudah dilindungi oleh UU. Data BPS itu harus menjadi data basis segala perencanaan, namun data BKKBNlah yang mendekati kebenaran di lapangan dalam kasus berkurangnyajumlah raskin yang diterima oleh setiap KK di Kelurahan Tempuling.

Disinilah persoalan terjadi, kriteria terhadap rumah tangga yang dikatakan miskin harus jelas. Sebab selama ini sosialisasi terhadap rumah tangga miskintidak tersosialisasi dengan baik. Aparat Desa/Kelurahan harus tahu betul bahwa kriteria rumah tangga miskin yang ditetapkan pemerintah adalah masyarakat yang penghasilan maksimumnya sebulan Rp 500,000,-, pola makan dari keluarga tersebut 1-2 per hari, atau rumah tangga miskin yang makan hanya satu kali itu pun bukan beras tapi pengganti makanan pokok lainnya seperti ubi, singkong, gaplek, jagung dan sebagainya.Jika masyarakat tidak termasuk kedalam kriteria tersebut, maka dia tidak bisa digolongkan masyarakat miskindan dia tidak berhak menerima raskin. Namun kenyataan dilapangan, banyak masyarakat yang tidak tergolong kriteria diatas memperoleh raskin. Hal ini tentu harus menjadi perhatian lembaga terkait dalam pengawasan pendistribusian raskin.

Selain itu, pembagian raskin dilakukan secara merata termasuk kepada rumah tangga miskin yang namanya tidak terdaftar dalam DPM raskin dan kepada rumah tangga yang tidak tergolong miskin. Atas dasar musyawarah atau kebijakan desa/lurah terkait, raskin dibagikan hampir keseluruh rumah tangga miskin di kelurahan tersebut. Hal tersebut dilakukan untuk menghindari kecemburuan sosial dari rumah tangga yang tidak menerima raskin. Hal ini berbanding terbalik dengan hasil penelitian Damanik (2012) di Kelurahan Tanjung Marulak Kecamatan Rambutan Kota Tebing Tinggiyang berpendapat bahwapendistribusian raskin tidak efektif karena 12 sampel atau 40\% tidak tepat sasaran. Hal tersebut dikarenakan pendapatan yang diatas UMR kota Tebing Tinggi sebesar Rp. 1.280.000/bulan.

\subsubsection{Tepat Jumlah}

Buruknya pencapaian sasaran menyebabkan target penyaluran semakin berkurang dari $15 \mathrm{Kg}$ menjadi $10 \mathrm{Kg}$ hingga 7,5 per rumah tangga miskin per bulan. Sebab banyak penerima manfaat diluar target. Raskin disalurkan kepada mereka yang datang lebih awal dan mampu menebusnya. Masyarakat paling miskin hanya mampu menebus beras bersubsidi itu sekitar $15 \mathrm{Kg}$ per $\mathrm{RTM} / 2$ bulan. Hal ini sejalan dengan pernyataan Bayu Dwi Radius dalam Kompas (24 Juli 2007) bahwa Rp 1600 per Kg disamping mereka tidak menyadari perlunya menyediakan dana tambahan. Akibatnya beras tidak sampai kesasaran.

Kecilnya jumlah raskin yang diterima masyarakat miskin dikarenakan semakin bertambahnya jumlah keluarga miskin yang ada didaerah penelitian. Berdasarkan data BPS jumlah masyarakat miskin di Kelurahan Tempuling adalah 205 KK. Namun masih ada masyarakat yang tergolong miskin tidak termasuk kedalam data BPS, tetapi pihak Kelurahan tetap memberikan mereka raskin.Sehingga sewaktu pembagian raskin di Kelurahan Tempuling terjadi pembagian yang sama rata dengan jatah masingmasing KK sebanyak $15 \mathrm{Kg} / 2$ 
bulandengan tujuan untuk menghindari keributan sewaktu pembagian raskin.

Kekurangan jumlah beras yang diterima oleh rumah tangga miskin pada saat pendistribusian beras menyebabkan banyak keluarga yang mengeluh karena jumlah beras yang diberikan semakin tidak mencukupi kebutuhan. Hal ini dapat dilihat pada tabel 11yang menunjukkan bahwa $100 \%$ responden mengatakan jumlah raskin yang diterima keluarga miskin adalah $15 \mathrm{Kg} / \mathrm{KK} / 2$ bulan. Ini menunjukkan ketidak efektifan program pendistribusian raskin yang dilihat dari ketepatan jumlah beras yang diterima. Hal ini berbanding terbalik dengan hasil penelitian Damanik (2012) di Kelurahan Tanjung Marulak Kecamatan Rambutan Kota Tebing Tinggi yang berpendapat pendistribusian raskin sudah efektif jika dilihat dari ketepatan jumlah karena penerima manfaat raskin menerima raskin sebanyak $15 \mathrm{~kg}$ yang sudah dalam bentuk karung goni ukuran $15 \mathrm{~kg}$.

\subsubsection{Tepat Harga}

Harga raskin yang semestinya dijual kepada rumah tangga miskin yaitu sebesar Rp 1600 per netto di titik distribusi. Harga tersebut merupakan harga yang telah yang ditetapkan oleh pemerintah. Tabel 11 menunjukkan bahwa dari 69 sampel, tidak ada keluarga yang mengatakan raskin dijual seharga $\mathrm{Rp} 1600 / \mathrm{Kg}$. Harga raskin yang dibeli oleh rumah tangga miskin yaitu Rp 2200/Kg. Hal ini karena sebagian daerah Kelurahan Tempuling cukup jauh, sehingga diperlukan transportasi untuk menuju ke daerah tersebut. Dapat disimpulkan untuk ketepatan harga distribusi raskin tidak efektif.Hal inisebanding dengan hasil penelitian
Damanik (2012) di Kelurahan Tanjung Marulak Kecamatan Rambutan Kota Tebing Tinggi yang berpendapat penerima manfaat raskin memperoleh raskin dengan harga $\mathrm{Rp}$. $1.700 / \mathrm{kg}$. Hal ini terjadi karena penerima Raskin dibebankan biaya bongkar muat dan biaya jaga malam serta keuntungan penyalur.

\subsubsection{Tepat Waktu}

Berdasarkan hasil penelitian dari 69 orang atau 100\% responden mengatakan bahwa pendistribusian beras miskin tidak tepat waktu. Hal tersebut menunjukkan terjadinya penyimpangan waktu penyaluran sehingga membuat program pendistribusian raskin tidak efektif. Hal ini karena sering terjadi keterlambatan-keterlambatan dalam pendistribusian yang seharusnya 12 bulan dalam setahun berkurang jadi 6 bulan dan jarak pendistribusian antar bulanberselang 2 bulan, sehingga rumah tangga penerima beras miskin merasa kesulitan memperoleh beras. Karena program raskin sangat membantu rumah tangga miskin dalam mengatasi masalah pangan. Keterlambatan penyaluran raskin tersebut juga disebabkan karena keterlambatan pembayaran hutangoleh tim raskin di Kecamatan/Kelurahan/Desa, maka pendistribusiana raskin untuk bulan berikutnya menjadi lambat. Hal ini senada dengan hasil penelitian Bakkara (2013) di Desa Sitalasari Kecamatan Siantar Kabupaten Simalungun yang berpendapat bahwa pendistribusian raskin $100 \%$ tidak efektif jika dilihat dari indikator ketepatan waktu. Hal tersebut karena pendistribusian raskin sering mengalami keterlambatan pengiriman yang jaraknya 3-4 bulan. 


\subsubsection{Tepat Kualitas}

Kualitas beras Raskin berdasarkan pedum adalah beras berkualitas medium kondisi baik dan tidak berhama, sesuai dengan standar kualitas pembelian pemerintah yang diatur dalam perundangundangan.Berdasarkan tinjauan dokumen, kualitas beras raskin yang diperoleh penerima manfaat bervariasi, sebagian besar cukup baik, namun terkadang buruk. Menurut Lembaga Demografi FEUI (2003: 24), kualitas beras yang kurang baik hanya terdapat pada beberapa karung saja.

Berdasarkan hasil penelitian, 32 orang atau $46 \%$ dari respondenmengatakan bahwa kulitas beras miskin tepat kualitas atau layak, sedangkan sebanyak 37 orang atau 54\% sampel mengatakan bahwa kualitas raskin tidak tepat atau tidak layak. Sebagian masyarakat mengatakan tidak layak karena raskin yang diterima terkadang bau apek, pera dan kotor. Sehingga sebagian masyarakat harus mengilang ulang raskin tersebut atau mencampurnya dengan beras lokal ketika dimasak. Hal tersebut menunjukkan di beberapa titik distribusi terjadi penyimpangan kualitas terhadap penyaluran sehingga membuat program pendistribusian raskin tidak efektif. Hal ini berbanding terbalik dengan hasil penelitian Bakkara (2013) di Desa Sitalasari Kecamatan Siantar Kabupaten Simalungun yang berpendapat bahwa pendistribusian raskin sudah efektif jika dilihat dari indikator ketepatan kualitas. Hal ini karena $87 \%$ dari sampel mengatakan kualitas raskin layak untuk dikonsumsi.

\subsubsection{Tepat Administrasi}

Berdasarkan hasil penelitian 49 responden atau $71 \%$ mengatakan pembayaran administrasi raskin di Kelurahan Tempuling selalu berjalan lancar dimana pembayarannya dilakukan secara tunai.Namun sebanyak 20 responden atau 29\% mengatakan apabila terdapat keluarga sasaran penerima manfaat raskin tidak mampu membayar tunai, maka pembelian raskin tersebut dialihkan kepada orang yang mampu membayar secara tunai atau ditunda sampai penerima manfaat raskin bisa membeli secara tunai. Selain itu, bagi penerima manfaat raskin yang tidak membawa karung pada waktu pembelian raskin akan dikenakan biaya tambahan sebesar Rp. 2000 untuk pembelian karung.Sehingga dapat disimpulkan bahwa pendistribusian raskin dari segi ketetapan administrasi dikatakan cukup efektif.Hal ini sebanding dengan hasil penelitian Bakkara (2013) di Desa Sitalasari Kecamatan Siantar Kabupaten Simalungun yang berpendapat bahwa $64 \%$ pendistribusin raskin sudah tepat jika dilihat dari indikator administrasi. Hal ini karena pendistribusian raskin Pembayaran dilakukan secara tunai oleh rumah tangga miskin yang memegang kartu Raskin kepada pelaksana distribusi di tingkat Kelurahan/Desa.

\subsection{Efisiensi}

Setiap lembaga pemasaran yang terlibat akan mengambil keuntungan untuk jasa yang mereka berikan. Kegiatan fungsi pemasaran oleh lembaga-lembaga pemasaran akan mengakibatkan timbulnya biaya pemasaran. Besarnya biaya pemasaran akan berpengaruh 
terhadap daya beli konsumen. Efisiensi pemasaran menghitung biaya pemasaran dibagi dengan nilai produk yang dipasarkan. Adapaun efisiensi pemasarn distibusi raskin dapat dilihat pada tabel 4 .

Tabel 4. Tingkat Efisiensi Pendistribusian Raskin di Kelurahan Tempuling Kecamatan Tempuling Kabupaten Indragiri Hilir

\begin{tabular}{|l|c|}
\hline \multicolumn{1}{|c|}{ Uraian } & Jumlah \\
\hline Total Pagu Raskin $(\mathrm{Kg})$ & 3.075 \\
\hline Harga Jual Raskin $(\mathrm{Rp} / \mathrm{kg})$ & 2.200 \\
\hline Total Penjualan Raskin $(\mathrm{Rp})$ & 6.765 .000 \\
\hline Biaya Distribusi $(\mathrm{Rp})$ & 1.021 .000 \\
\hline Efisiensi Pemasaran & 0,15 \\
\hline
\end{tabular}

Sumber : Data Primer diolah, 2017

Berdasarkan tabel 4 dapat dilihat bahwa total pagu raskin untuk daerah Kelurahan Tempuling yaitu $3.075 \mathrm{Kg}$ dengan RTM sebesar 205 KK. Harga raskin yang dijual tingkat rumah tangga miskin yaitu $2200 / \mathrm{Kg}$ yang mencakup biaya-biaya yang diperlukan dalam proses pendistribusian. Sehingga diperoleh total penjualan raskin kepada rumah tangga miskin yaitu sebesar Rp 6.765.000. Keseluruhan biaya distribusi yang dikeluarkan baik tingkat desa/lurah yaitu Rp 471.000.

Efisiensi

pemasaran

menghitung biaya-biaya selama proses pendistribusian/pemasaran dibagi dengan total penjualan terhadap konsumen akhir. Dari hasil perhitungan diketahui tingkat efisiensi pemasaran diperoleh sebesar 0,15 yang menunjukkan bahwa pendistribusian raskin adalah efisien. Dikatakan efisien karena hasil perhitungan efisiensi pemasaran (Ep) berada dibawah 1. Hasil perhitungan tersebut di dukung dengan biaya distribusi yang cukup rendah dibandingkan dengan nilai total penjualan raskin karena saluran pemasaran atau jalur pemasaran dalam pendistribusian raskin pendek yaitu pendistribusian langsung dari BULOG ke titik distribusi dan langsung ke rumah tangga miskin. hal ini sesuai dengan teori Mubyarto (1885) dimana sistem pemasaran dianggap efisien bila mampu menyampaikan hasil-hasil produsen kepada konsumen dengan biaya semurah-murahnya.

Pendistribusian raskin menggunakan rantai pemasaran beras yang pendek sehingga biaya yang dikeluarkan cukup minim. Beras disalurkan dari gudang BULOG langsung ke konsumen melalui perantara perangkat desa/lurah. Biaya pendistribusian yang rendah mempengaruhi tingkat efisiensi pemasaran. Hal ini didukung oleh Soekartawi (1993) bahwa pemasaran yang efisien akan terjadi jika biaya pemasaran dapat ditekan. Hal ini sebanding dengan hasil penelitian Sari (2007) yang berpendapat bahwa pendistribusian raskin di Desa Securai Utara termasuk kategori efisien, karena dapat dilihat dari efisiensi pemasaran $<1$.

\section{KESIMPULAN DAN SARAN}

\subsection{Kesimpulan}

1. Harga raskin di tingkat rumah tangga miskin yaitu sebesar Rp. $2.200 / \mathrm{Kg}$ sehingga terdapat perbedaan harga antara harga patokan pemerintah dengan 
harga di tingkat rumah tangga sebesar Rp. 600.

2. Program pendistribusian raskin di Kelurahan Tempuling tidak efektif karena dari 6 indikator (sasaran, jumlah, waktu, harga, kualitas dan administrasi) ratarata tingkat ketepatannya $31 \%$.

3. Program pendistribusian raskin di Kelurahan Tempuling tingkat efisiensinya 0,15 (efisien).

\subsection{Saran}

1. Sebaiknya dilakukan pendataan keluarga miskin oleh aparat paling rendah misalnya ketua RT/RW yang dapat mengamati dan menilai langsung tingkat kemiskinan warga mereka sehingga lebih tepat sasaran.

2. Anggaran distribusi raskin sebaiknya dimasukkan dalam anggaran Pendapatan daan Belanja Daerah (APBD) sehingga rakyat miskin dapat menerima dengan harga murah yaitu Rp. 1600/Kg.

3. Perlunya tambahan terhadap pagu raskin mengingat jumlah rumah tangga miskin yang semakin meningkat dan pembaharuan waktu pendistribusian yang disesuaikan dengan rencana distribusi.

\section{DAFTAR PUSTAKA}

Badan Pusat Statistik. 2015. Kemiskinan di Kabupaten Indragiri Hilir 2015. Badan Pusat Statistik. Riau

Bakkara. 2013. Analisis Efetifitas Distribusi Beras Miskin (Studi Kasus : Desa Sitalasari Kecamatan Siantar Kabupaten Simalungun).
Jurnal Fakultas Pertanian Universitas Sumatera Utara Medan.

Basri, Faisal. 2002. Perekonomian Indonesia "Tantangan dan Harapan BagiKebangkitan Ekonomi Indonesia". Jakarta: Erlangga

BULOG. 2006. Pedoman Umum Program Beras Untuk Keluarga Miskin (RASKIN). Direktorat Jenderal Pemberdayaan Masyarakat dan Desa Departemen Dalam Negeri dengan Perum Bulog.

Damanik, R. Analisis Efektivitas Distribusi Beras Miskin (Studi Kasus: Desa Sitalasari Kecamatan Siantar Kabupaten Simalungun). Jurnal Fakultas Pertanian Universitas Sumatera Utara, Medan.

Downey, W,. D,. dan S. P, Erickson. 1992. Manajemen Agribisnis. Erlangga, Jakarta.

Goudzwaard, B dan Lange. 1995. Di Balik Kemiskinan dan Kemakmuran. Yogyakarta: Kanisius

Lurah Tempuling. 2015. Penerima Pagu Raskin di Kelurahan Tempuling 2015. Lurah Tempuling. Kabupaten Indragiri Hilir.

Profil Kecamatan Tempuling. 2015. Penerima Pagu Raskin di Kecamatan Tempuling 2015. Kantor Camat Tempuling, Sungai Salak.

Purwadi, B. 2000. Riset Pemasaran. Grasindo, Jakarta.

Rahim, A dan Dwihastuti, D. R., 2007. Ekonomika Pertanian. Penebar Swadaya, Jakarta.

Sari, Y. 2007. Analisis Efektivitas dan Efisiensi Distribusi Raskin di Desa Securai Utara 
Kecamatan Balaban

Kabupaten Langkat. Skripsi.

Fakultas

Pertanian

Universitas Sumatera Utara, Medan.

Soekartawi. 2002. Analisis Usaha Tani. Jakarta: UI-Press

Sugiarto, Dkk. 2000. Ekonomi Mikro

; Suatu Pendekatan Praktis. Gramedia Pustaka Utama, Jakarta.

Sulaksono, B., 2003. Kebijakan

Bulog Dalam Pengadaan
Beras. http // www. smere. or.

Id/ newslet/2003/ ed05/

200305. Field.htm.06 maret 2017.

Taff, C A., 1994. Manajemen Transportasi dan Distribusi Fisis. Erlangga, Jakarta..

Umar, Husein, 2003. Metode Riset Akuntansi Terapan. Cetakan Pertama. Penerbit Ghalia Indonesia: Jakarta 